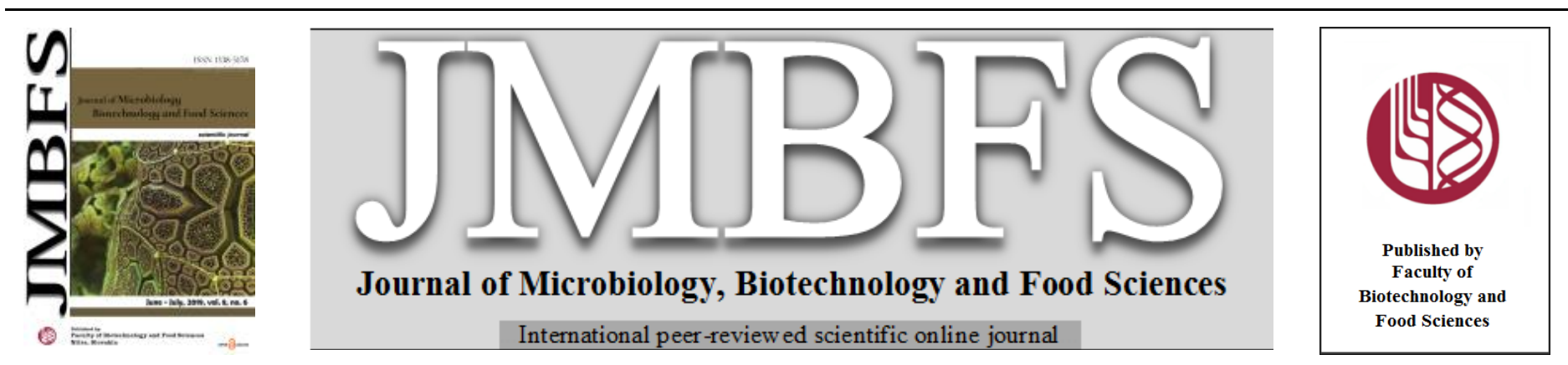

\title{
BIOLOGICAL ACTIVITY OF ENDOMETABOLITES FROM SUGAR BEET (BETA VULGARIS L.) PERICARPS
}

\author{
Klyachenko Oksana*1, Likhanov Artur ${ }^{2}$
}

Address(es): Klyachenko Oksana,

${ }^{1}$ University of Life and Environmental Sciences of Ukraine, Faculty of Plant Protection, Biotechnology and Ecology, Department ecobiotechnology and biodiversity, 15 Heroev Oborony str., Kiev 03041, Ukraine, +38 044 527-85-17.

${ }^{2}$ Institute for evolutionary ecology of the National Academy of Sciences of Ukraine, Department of Dendrology, 37 Lebedeva str., Kiev 03143, Ukraine +38 (063) 619$19-71$.

*Corresponding author: Klyachenko@ukr.net

doi: 10.15414/jmbfs.2019.8.6.1303-1306

\section{ARTICLE INFO}

Received 15. 7. 2018

Revised 30. 1. 2019

Accepted 4. 2. 2019

Published 1. 6. 2019

Regular article

OPEN $\partial_{\text {ACCESS }}$

\begin{abstract}
Biologically active compounds of secondary metabolism are crucial for the regulation of seed germination and sprout development. The pericarp of sugar beet (Beta vulgaris L.) contains such substances. The research was focused on the extraction of the secondary metabolites and the effect of multicomponent endometabolites from sugar beet pericarps on the germination of plant seeds. The chemical composition of the metabolites and sugar beet pericarps was determined by thin-layer chromatography; differentiated separation was carried out using column chromatography and gel filtration; the total content of phenolic compounds in seed balls and pericarps was determined by the method of spectrophotometry. Pericarps of sugar beet contain a great number of phenolic compounds that have a protective function. We selected four groups of phenolic compounds of different molecular weights, the share of which averaged 5-10\%. When studying the effect of aqueous extracts on radish seeds it was found that the eluents of the first volumes of water (3-5 $\mathrm{ml})$ showed a clear stimulating effect, while further volumes of eluents $(8-9 \mathrm{ml})$ had inhibitory action. In extracts of sugar beet pericarps, phenols, flavonoids and their glycosides were found, which are highly active inhibitors and growth promoters and can be used as natural biologically active compounds.
\end{abstract}

Keywords: sugar beet, pericarp, biologically active compounds, phenols, flavonoids

\section{INTRODUCTION}

Biologically active compounds play an important role in the regulation of seed germination and sprout growth and development, particularly hormones (abscisic acid, ethylene) (Alberdi, Corcuera, 1991; Hermann et al., 2007), polyphenols (hydroxi-cinnamic acids, flavonoids, tannins, flavolignans) (Blazhey, 1977; Pourcel et al., 2006), coumarins (Adkins, Bellairs, Loch, 2002) and saponins (Vasilieva, 2000). Pericarps of sugar beet seed ball formed from walls of fruit during the formation of the embryo vary with the formation of various tissue structures: exocarp, mesocarp, and endocarp (Comparative anatomy of seeds, 1991), which functions are due to the peculiarities of anatomical structure, chemical nature and distribution of metabolites. It is shown that highly active compounds that can significantly affect germination of sugar beet seeds (Beto vulgaris L.) can be found predominantly in pericarp (Chiji, Tanaka, Izawa, 1980; Taylor et al., 2003), especially in mesocarp tissue (Juntilla, 1976).

The known secondary metabolites of sugar beet are mainly represented by isoflavones, flavonones, dihydroflavonols and their glycosides (betavulgarin, betagarin, irisone B) having the properties of phytoalexins (antifungal and antibacterial activity); betalamine alkaloids (betalamic acid as a predecessor of betalaines and xanthines), which are pigments and antioxidants; simple indoles and bisindole alkaloids, isoindoles (inhibitors of germination for Beta $s p$.); diterpenoids and triterpenoids (saponins), for example, glycosides of oleanolic acid, caryophyllene, hederagenin and bisdesmosites (with antibacterial, ihtiotoxic antiulcerogenic action) (Dictionary of Natural Products, ver.22., 2014).

The purpose of this research was to separate the water-soluble compounds from the residues of sugar beet pericarps into fractions and to investigate their biological activity.

\section{MATERIAL AND METHODS}

\section{Extraction of polar compounds}

The polar compounds from the pericarp residues of Ivanivskyi MS 33 hybrid were extracted in double-distilled water at $40^{\circ} \mathrm{C}$ for $24 \mathrm{~h}(1: 10)$. Gel filtration was carried out to separate substances in a column of $9 \mathrm{~mm}$ in diameter and 150 $\mathrm{mm}$ in height filled with Sephadex G-25.

\section{HPLC аналіз}

Secondary metabolite profiling was performed by DAD-RP-HPLC on Agilent 1100 system using 2-eluent scheme (eluent $\mathrm{A}=0,05 \mathrm{M}$ aqueous solution of $\mathrm{H}_{3} \mathrm{PO}_{4} ; \mathrm{B}=$ acetonitrile), column - Agilent Poroshell ${ }^{\circledR} 120,2.7 \mu \mathrm{m}, 2.1 \times 150$ $\mathrm{mm}$, temperature control $20^{\circ} \mathrm{C}$, sample volume $5 \mu \mathrm{l}$, flow rate $0.2 \mathrm{ml} / \mathrm{min}$, analysis time up to $80 \mathrm{~min}$, elution profile - wide range linear gradient from $0 \%$ $\mathrm{B}$ in $\mathrm{A}$ to $100 \% \mathrm{~B}$ in $30 \mathrm{~min}$, then isocratic $\mathrm{B}$ with flow accelerated to $0.6 \mathrm{ml} / \mathrm{min}$ and column temperature increased to $40^{\circ} \mathrm{C}$. Wavelength detection at 206, 254, 300,350 and $450 \mathrm{~nm}$ was used to determine the most organic compounds (including terpenoids), most of substances with aromatic structure in molecule, phenylpropanoids (mainly cinnamic acids), flavonoids (flavones and flavonols), carotenoids and chlorophylls, respectively. The spectra were recorded at peak maximum in the range $200-800 \mathrm{~nm}$ in order to elucidate the nature of secondary metabolites and attribute to certain groups of substances. This is not an exact chemical identification but the assumption based on the chromatographic behavior and spectra of separated components. Thus, flavones and flavonols are characterized by two distinct maximums at 260 and $350 \mathrm{~nm}$. Lots of phenylpropanoids (hydroxycinnamic acids) and also isoflavones, flavanones, dihydroflavonols - by large maximum (often with shoulder) at 300-320 nm. Cinnamic itself, hydroxybenzoic acids and lignans have an absorption maximum in the range 280-300 nm [Dictionary of Natural Products, ver. 22.2 Copyright (C 2014 Taylor \& Francis Group. - URL: http://dnp.chemnetbase.com (2014)] Reproducibility of HPLC analysis was monitored using the mixture of nine alkylphenones (Sigma-Aldrich) from acetophenone to myristophenon. The error of sample injection does not exceed $2 \%$, while the retention time deviation mostly ranges within $5 \%$. Processing and visualization of chromatograms and absorption spectra were carried out using Agilent ChemStation ${ }^{\circledR}$ and CorelDraw ${ }^{\circledR}$ software. 


\section{Determination of phenolic compounds}

The total content of phenolic compounds in the extracted fractions was determined with the aid of spectrophotometric method (scanning spectrophotometer, Optizen Pop, South Korea) using the Folin \& Ciocalteu's reagent (Sigurbjoorsson, 1995). The calibration graph was drawn in terms of gallic acid (Merk, Germany).

\section{Determination of flavonoids}

The content of flavonoids was determined spectrophotometrically (at $\lambda=419$ $\mathrm{nm}$ ) through successive addition of $200 \mu$ of the separated fractions of the extract to $200 \mu \mathrm{l}$ of $0.1 \mathrm{M}$ solution of $\mathrm{AlCl}_{3}$ and $300 \mu \mathrm{l}$ of $1 \mathrm{M} \mathrm{CH}_{3} \mathrm{COONa}$. The calibration graph was drawn in terms of quercetin (Merk, Germany) (Laboratory manual on pharmacognosy, 2003).

\section{Determination of phytotxic activity of metabolites}

The phytotoxic activity of metabolites from the pericarp residues was studied on pure test cultures of Chlorella vulgaris 106 on solid nutrient media. Aqueous extract of the pericarp residues $(30 \mu \mathrm{l})$ was introduced into cells of $6 \mathrm{~mm}$ in diameter. Test culture was incubated in a thermostat at $+25^{\circ} \mathrm{C}$. The biologica activity of the extracted substances was evaluated in terms of growth inhibition as following; on the 5th, 7th and 12th day (Grodzinskii, 1983).

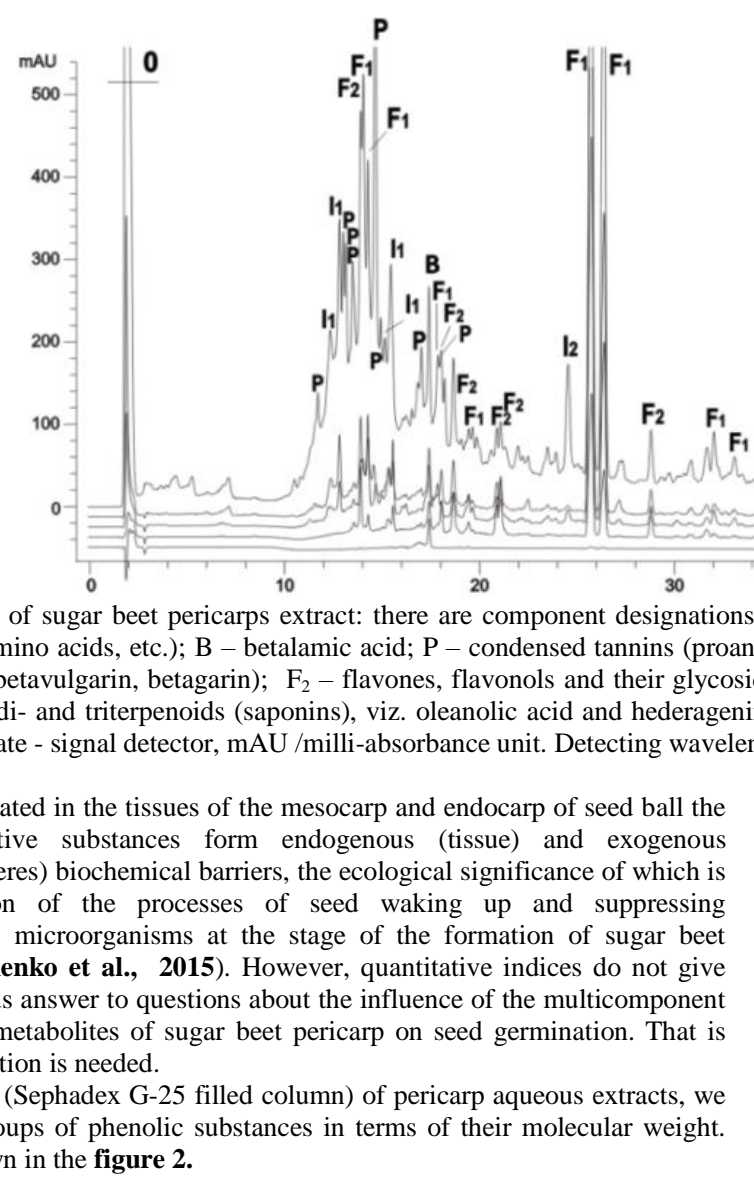

Figure 1 HPLC of sugar beet pericarps extract: there are component designations: 0 - components with no retention (hydrophilic substances restrained pool (free organic acids, amino acids, etc.); $\mathrm{B}$ - betalamic acid; $\mathrm{P}$ - condensed tannins (proanthocyanidins); $\mathrm{F}_{1}$ - isoflavones, flavanones, dihydroflavonols and their glycosides (viz. irisone $\mathrm{B}$, betavulgarin, betagarin); $\mathrm{F}_{2}$ - flavones, flavonols and their glycosides; $\mathrm{I}_{1}$ - simple indole and bisindole alkaloids; $\mathrm{I}_{2}-$ isoindoles (Beta germination inhibitor); $\mathrm{T}$-di- and triterpenoids (saponins), viz. oleanolic acid and hederagenin glycosides and bisdesmosides; $\mathrm{S}-\mathrm{sterols}$ and their esters. Abscissa - retention time, min, ordinate - signal detector, mAU /milli-absorbance unit. Detecting wavelengths designated five channels .
Having accumulated in the tissues of the mesocarp and endocarp of seed ball the biologically active substances form endogenous (tissue) and exogenous (phytogenic spheres) biochemical barriers, the ecological significance of which is active regulation of the processes of seed waking up and suppressing phytopathogenic microorganisms at the stage of the formation of sugar beet sprouts (Klyachenko et al., 2015). However, quantitative indices do not give any unambiguous answer to questions about the influence of the multicomponent system of endometabolites of sugar beet pericarp on seed germination. That is why their separation is needed.

By gel filtration (Sephadex G-25 filled column) of pericarp aqueous extracts, we isolated four groups of phenolic substances in terms of their molecular weight Results are shown in the figure 2.

\section{Determination of bacteriostatic effect of the extracts}

To determine the bacteriostatic effect of the extracts, $0.1 \mathrm{~g}, 0.5 \mathrm{~g}$ and $1.0 \mathrm{~g}$ of thoroughly mixed and incubated in a thermostat at $+25^{\circ} \mathrm{C}$ for $24 \mathrm{~h}$ in sterilized test tubes. Soil sampling for the experiment was carried out in agricultural plots from a depth of $3-5 \mathrm{~cm}$. The experiment was carried out in five replication. The bacteria from the soil samples were cultured under sterile conditions on the Zvyagintsev nutritional medium (Zvyagintsev, 1987).

\section{Statistical analysis}

The results of biotests were analysed using the specialized program Image ProPremier 9.1. Statistical data was processed using Statistica 6.0.

\section{RESULTS AND DISCUSSION}

\section{Extraction and study of biologically active substances from pericarp}

According to published data, polar chemical compounds of sugar beet pericarp are known to have the ability to inhibit seed germination in many plant species. Medium polar inhibitors include flavonoids, bisalkaloids and isoindole compounds (Morris, Grierson, Whittington, 1984). In previous research, we found that in most studied genotypes of sugar beet, pericarp of seed ball contains complexes of compounds with clear biologically active action. Most of those compounds are salts of carboxylic acids and phenolic compounds: condensed tannins (proanthocyanidins, isoflavones, dihydroflavonols, flavones, flavonols and their glycosides, as well as simple indoles, isoindoles (inhibitors of germination), bisindole alkaloids, diterpenoids and triterpenoids (glycosides of caryophyllene, hederagenin and bisdesmosites) (figure 1). pericarp residues of Ivanivskyi MS 33 hybrid were added to $10 \mathrm{~g}$ of wet soil,
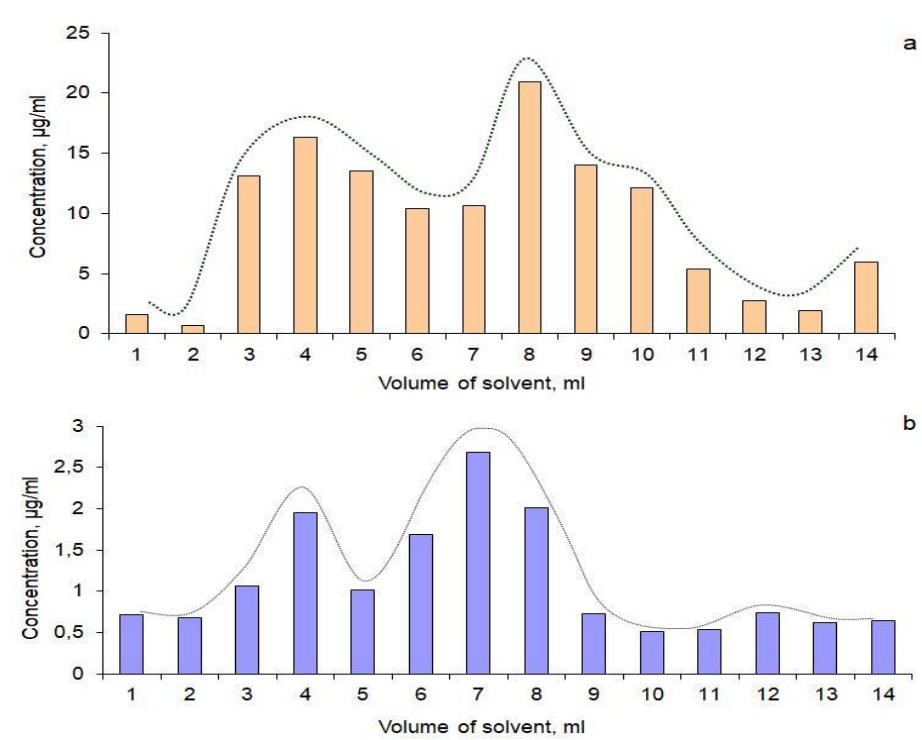

Figure 2 Separation of phenols (a) and flavonoids (b) of aqueous extracts of sugar beet pericarps using Sephadex G-25 column 
Indicators of the ratio of phenolic compounds to flavonoids in the extracts of seed balls and pericarp residues had four maxima in terms of their molecular weight

Table 1 Distribution of phenols (Fn) and flavonoids $(\mathrm{Fl})$ in the volume of solvent $(\mathrm{n}=4)$

\begin{tabular}{|c|c|c|c|c|c|c|c|c|}
\hline \multirow{2}{*}{$\begin{array}{l}\text { V, } \\
\text { мЛ }\end{array}$} & \multicolumn{3}{|c|}{$\mathrm{Pl}(\mathrm{Sb})^{*}$} & \multicolumn{3}{|c|}{ Per * } & \multicolumn{2}{|c|}{ Per / Pl (Sb) } \\
\hline & $\mathrm{Fn} *$ & $\mathrm{Fl}^{*}$ & $\mathrm{Fn} / \mathrm{Fl}$ & Fn & $\mathrm{Fl}$ & $\mathrm{Fn} / \mathrm{Fl}$ & Fn & $\mathrm{Fl}$ \\
\hline 1 & $1,6 \pm 0,06$ & $0,7 \pm 0,03$ & $2,2 \pm 0,09$ & $3,6 \pm 0,15$ & $1,1 \pm 0,04$ & $3,4 \pm 0,14$ & $2,3 \pm 0,09$ & $1,5 \pm 0,06$ \\
\hline 2 & $0,7 \pm 0,03$ & $0,7 \pm 0,03$ & $1,0 \pm 0,04$ & $18,4 \pm 0,74$ & $2,2 \pm 0,09$ & $8,4 \pm 0,33$ & $28,2 \pm 1,13$ & $3,2 \pm 0,13$ \\
\hline 3 & $13,1 \pm 0,52$ & $1,1 \pm 0,04$ & $12,2 \pm 0,49$ & $99,0 \pm 3,96$ & $10,7 \pm 0,43$ & $9,3 \pm 0,37$ & $7,6 \pm 0,30$ & $\mathbf{1 0 , 0} \pm \mathbf{0 , 4}$ \\
\hline 4 & $16,4 \pm 0,65$ & $2,0 \pm 0,08$ & $8,4 \pm 0,34$ & $77,8 \pm 3,11$ & $7,0 \pm 0,28$ & $11,1 \pm 0,44$ & $4,8 \pm 0,19$ & $3,6 \pm 0,14$ \\
\hline 5 & $13,6 \pm 0,54$ & $1,0 \pm 0,04$ & $13,4 \pm 0,54$ & $35,1 \pm 1,40$ & $2,8 \pm 0,11$ & $12,4 \pm 0,50$ & $2,6 \pm 0,10$ & $2,8 \pm 0,11$ \\
\hline 6 & $10,4 \pm 0,42$ & $1,7 \pm 0,07$ & $6,2 \pm 0,25$ & $31,3 \pm 1,25$ & $1,7 \pm 0,07$ & $18,9 \pm 0,76$ & $3,0 \pm 0,12$ & $1,0 \pm 0,04$ \\
\hline 7 & $10,6 \pm 0,42$ & $2,7 \pm 0,11$ & $4,0 \pm 0,16$ & $36,9 \pm 1,48$ & $2,4 \pm 0,10$ & $15,3 \pm 0,61$ & $3,5 \pm 0,14$ & $0,9 \pm 0,04$ \\
\hline 8 & $20,9 \pm 0,84$ & $2,0 \pm 0,08$ & $10,4 \pm 0,42$ & $41,4 \pm 1,66$ & $2,4 \pm 0,10$ & $16,9 \pm 0,68$ & $2,0 \pm 0,08$ & $1,2 \pm 0,05$ \\
\hline 9 & $14,0 \pm 0,56$ & $0,7 \pm 0,03$ & $19,1 \pm 0,76$ & $45,0 \pm 1,80$ & $2,8 \pm 0,11$ & $15,9 \pm 0,64$ & $3,2 \pm 0,13$ & $3,8 \pm 0,15$ \\
\hline 10 & $12,1 \pm 0,49$ & $0,5 \pm 0,02$ & $23,6 \pm 0,94$ & $35,7 \pm 1,43$ & $1,9 \pm 0,08$ & $18,6 \pm 0,74$ & $2,9 \pm 0,12$ & $3,7 \pm 0,15$ \\
\hline 11 & $5,4 \pm 0,22$ & $0,5 \pm 0,02$ & $10,2 \pm 0,41$ & $22,5 \pm 0,90$ & $1,2 \pm 0,05$ & $19,5 \pm 0,78$ & $4,2 \pm 0,17$ & $2,2 \pm 0,09$ \\
\hline 12 & $2,8 \pm 0,11$ & $\mathbf{0 , 7} \pm \mathbf{0 , 0 3}$ & $3,8 \pm 0,15$ & $20,4 \pm 0,82$ & $1,9 \pm 0,07$ & $10,9 \pm 0,44$ & $7,3 \pm 0,29$ & $2,5 \pm 0,10$ \\
\hline 13 & $1,9 \pm 0,08$ & $0,6 \pm 0,02$ & $3,1 \pm 0,12$ & $9,4 \pm 0,38$ & $1,0 \pm 0,04$ & $9,4 \pm 0,38$ & $4,9 \pm 0,20$ & $1,6 \pm 0,06$ \\
\hline 14 & $6,0 \pm 0,24$ & $0,6 \pm 0,03$ & $9,3 \pm 0,37$ & $9,2 \pm 0,37$ & $0,7 \pm 0,03$ & $13,0 \pm 0,52$ & $1,5 \pm 0,06$ & $1,1 \pm 0,04$ \\
\hline
\end{tabular}

Note: * Fn - phenolic compounds; Fl - flavonoids; Pl (Sb) - seed balls; Per - pericarp; maximum values marking successive output of a separate fraction of phenolic compounds in the process of gel filtration of extracts are given in bold

The high content of phenols in aqueous extracts of pericarp residues compared to the ones of seed balls was due to better conditions for the dissolution of secondary metabolites in the solvent during the grinding of pericarps in the process of purification of sugar beet seeds.

Study of phytotoxic and bacteriostatic action of endometabolites
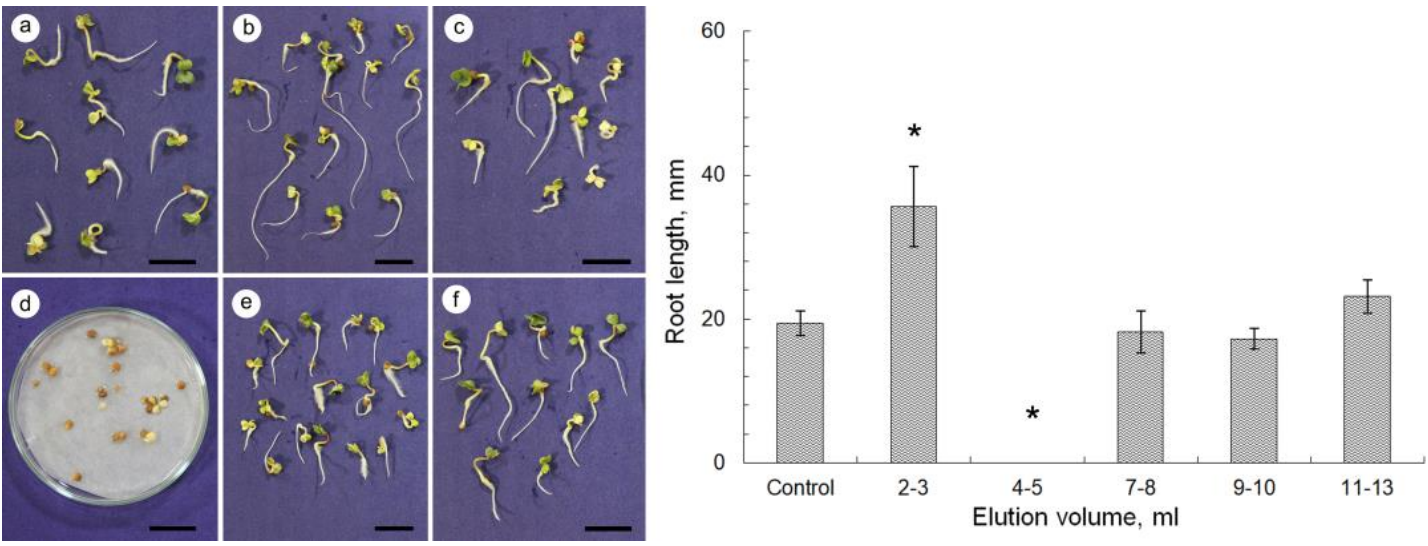

Figure 3 Influence of endometabolites of pericarp beet on germination of radish seeds: a - control treatment; $b-2-3 \mathrm{ml}$ of solvent; $\mathrm{c}-4-5 \mathrm{ml}$; $\mathrm{d}-7-8 \mathrm{ml}$; $\mathrm{e}-9-10 \mathrm{ml}$; $\mathrm{f}-11-13 \mathrm{ml}$; bar $-20 \mathrm{~mm}$; * - різниця достовірна по відношенню до контролю при $\mathrm{p}<0.05$, significant difference relative to the control $\mathrm{p}<0.05$
The model of the formation of endogenous and exogenous biochemical barriers, which was developed by us on the basis of empirical data, was confirmed in the course of the experiment. Results are shown in the figure 4.
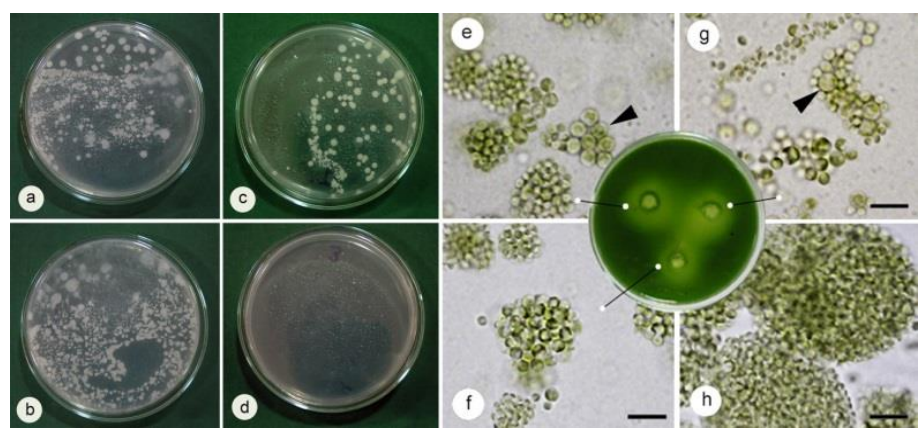

Figure 4 Effect of aqueous extracts of pericarps on soil microorganisms and propagation of chlorella cells: $\mathrm{a}, \mathrm{b}$ - results of soil microorganism culture from soil samples; c, d - when sugar beet seed balls are incorporated into the soil; e, f, $\mathrm{g}$ - aggregation of chlorella cells when adding seed ball extracts; $\mathrm{k}(\mathrm{c})$ - control treatment
The biological activity of the isolated compounds was different in terms of type of action. To illustrate, the eluents of the first volumes $(3 \mathrm{ml})$ of water stimulated the germination of radish seeds. Substances contained in the following volumes of eluents (4-5 ml) had inhibitory action. This indicates that there are both highly active inhibitors and growth promoters among the endometabolites of the sugar beet pericarps (figure 3 ) microorganisms decreased. The inverse relationship was found between the number of colonies formed on agar nutrient medium and the concentration of seed ball residues per unit volume of soil.

Consequently, water-soluble fractions in the process of gradual leaching from pericarp tissues can create a specific biochemical sphere in the soil around the seed that for some time inhibits the development of certain types of microorganisms and fungi that potentially can do harm to young sprouts of sugar beet at the early stages of their development. Sugar beet seed germination was increasing along with increasing soil moisture, with the number of microorganisms' colonies decreasing. Results are shown in the figure $\mathbf{4}$ a-d.

The content of biologically active compounds in sugar beet pericarps revealing phytoelicite properties of phytoelicitors (isoflavones, flavanones, dihydroflavonones and their glycosides) and seed germination inhibitors (simple indoles and bisindole alkaloids) allows us to consider the possibility of utilisation of seed residues.

It is known that pericarp makes about $75-85 \%$ of seed ball (Oehme J. Rüben, 1981). As $1 \mathrm{~g}$ of pericarps contains 20 to $40 \mathrm{mg} / \mathrm{g}$ phenolic compounds, according to our previous research (Klyachenko et al., 2015), from $1 \mathrm{~kg}$ of pericarp residues up to $40 \mathrm{~g}$ of phenolic metabolites, indole alkaloids and triterpene saponins can be extracted. In the process of purifying and coating seeds, seed residues will be up to $800 \mathrm{~g} / \mathrm{kg}$, consequently, the maximum amoun of secondary metabolites that can be extracted from $1 \mathrm{~kg}$ of seed residues will be 
15-30 g of valuable organic compounds of commercial interest and can be used as natural biologically active substances.

\section{CONCLUSION}

As a result of the conducted studies it was established that in the pericarp of sugar beet fruits there are compounds with a pronounced biologically active effect. In the extracts of sugar beet pericarps, there are phenols, flavonoids and their glycosides that are highly active inhibitors and growth promoters and therefore can be used as natural biologically active substances.

\section{REFERENCES}

ALBERDI M., CORCUERA L.J. 1991. Cold acclimation in plants.

Phytochemstry. 30, 3177-3184.

HERMANN K., MEINHARD J., DOBREV P. LINKIES A., PESEK B., HEß B., MACHAČKOVA, FISCHER U., LEUBNER-METZGER G. 2007. 1-

Aminocyclopropane-1-carboxylic acid and abscisic acid during the germination of sugar beet (Beta vulgaris L.): a comparative study of fruits and seeds. Journ. of Experimental botany. 58(11), 1-14.http://dx:doi:10.1093/jxb/erm162. https://doi.org/10.1093/jxb/erm162

BLAZHEJ A. 1977. Fenol'nye soedinenija rastitel'nogo proishozhdenija. M.: Mir. $239 \mathrm{~s}$.

CHIJI H., TANAKA S., IZAVA M. 1980. Phenolic germination inhibitors in the seed balls of red beet (Beta vulgaris L. var. rubra). Agric. Biol. Chem. 44 (1) 205-207. https://doi.org/10.1080/00021369.1980.10863924

ADKINS S.W., BELLAIRS S.M., LOCH D.S. 2002. Seed dormancy mechanisms in warm season grass species. Euphytica. 126, 13-20. https://doi.org/10.1023/A:1019623706427

VASIL'EVA I.S. 2000. Steroidnye glikozidy rastenij i kul'tury kletok dioskorei, ih metabolizm i biologicheskaja aktivnost'. Uspehi biologicheskoj himii. 40, 153 - 204.

SRAVNITEL'NAJA ANATOMIJA SEMJAN. 1991. T.3. Dvudol'nye Caryophyllidae - Dileniidae. - L.: Nauka. 77-78

JUNTILLA O. 1976. Germination inhibitors in fruit extracts of red beet (Beta vulgaris cv. rubra). Journal of experimental botany. 27, 827-836.

DICTIONARY OF NATURAL PRODUCTS, ver.22. - 2014. - Taylor and Francis Group. - URL: http: // dnp. chemnetbase. com (2014).

PRACTIKUM PO FARMAKOGNOZII: uch. posobie dlja stud. vuzov. 2003. / V.N. Kovalev, N.V. Popova, V.S. Kislichenko i dr.; pod red. V.N. Kovaleva. Har'kov: Izd-vo NFaU. Zolotye stranicy, 512 s. ISBN 966-615-192-8

GRODZINSKIJ D.M. 1983. Nadezhnost' rastitel'nyh sistem. K.: Nauk. dumka, $368 \mathrm{~s}$.

ZVJAGINCEV D.G. 1987. Pochva i mikroorganizmy. - M.: Izd-vo MGU, 256 s. SIGURBJOORSSON E. 1995. Application of in vitro mutation techniques for crop improvement. Euphytica. 85, 303-315. https://doi.org/10.1007/BF00023960 MORRIS P.C., GRIERSON D., WHITTINGTON J. 1984. Endogenous inhibitors and germination of Beta vulgaris L. Journal of Experimental Botany. 35(156). 994-1002. https://doi.org/10.1093/jxb/35.7.994

KLYACHENKO O.L., LIKHANOV A.F., GRAHOV V.P. 2015. Bar'ernye

funkcii perikarpiev saharnoj svekly (Beta vulgaris L.) razlichnyh genotipov.

Fiziologija rastenij i genetika. 47(5). 420-429.

OEHME J. Rüben. 1981. Zuckerrübe. In: Seiffert M. (Hrsg.) Pflanzenproduction. Drusch- und Hacrfruchtproduction. VEB Deutscher Ladwirtschaftsverlag Berlin, 302-374.

POURCEL L., ROUTABOUL J.-M., CHEYNIER V., LEPINIEC L., DEBEAUJON I. 2006. Flavonoid oxidation in plants: from biochemical properties to physiological functions // Trends in Plant Science,. - V.12 №.1. - P. 29-36. https://doi.org/10.1007/s12393-015-9119-x.

TAYLOR A.G., Goffinet M.C., Pikuz S.A., Shelkovenko T.A., Mitchell M.D. Chandler K.M., Hammer D.A. Physico-chemical factors influence beet (Beta vulgaris L.) seed germination/ The biology of seeds: recent research advances.Eds G. Nicolas, K.J. Bradford, D. Come, H.W. Pritchard -2003. - P. 433-440. ISBN 0-85199-653-1. 